\title{
A Simple Colorimetric Method for the Determination of Carbofuran and its Application in Environmental and Biological Samples
}

\author{
Urmila Tamrakar, ${ }^{a}$ Ajai K. Pillai ${ }^{*, a}$ and Vinay K. Gupta ${ }^{b}$ \\ ${ }^{a}$ Chemistry Department, Govt. V.Y.T. PG Autonomous College, Durg (C.G.) 491001, India \\ ${ }^{b}$ School of Studies in Chemistry, Pt. Ravishankar Shukla University, Raipur (C.G.) 492011 India
}

\begin{abstract}
Um método espectrofotométrico simples, baseado na reação de um pesticida carbamato, carbofurano (2,3-diidro,2,2-dimetil-7-benzofuranil metil carbamato), com o sal diazônio da $p$-aminoacetofenona (PAAPD) sob condições alcalinas é descrito. O corante laranja formado pela reação do pesticida com o PAAPD foi medido em $460 \mathrm{~nm}$. A lei de Beer é obedecida no intervalo de concentração de 0,1 a $1,2 \mu \mathrm{g} \mathrm{mL}^{-1}$ de carbofurano em uma solução final de $25 \mathrm{~mL}$. A absortividade molar e sensitividade de Sandell encontradas foram $1,2 \times 10^{5}$ $\mathrm{L} \mathrm{mol}^{-1} \mathrm{~cm}^{-1}$ e $0,0014 \mu \mathrm{g} \mathrm{cm}^{-2}$, respectivamente. As condições ótimas de reação e outras condições analíticas foram avaliadas. $\mathrm{O}$ efeito de íons interferentes na determinação de carbofurano é descrito. O método foi aplicado com sucesso na determinação de carbofurano em arroz, germe de trigo e várias amostras biológicas e ambientais. Os resultados obtidos foram comparados com outros métodos espectrofotométricos e cromatográficos estabelecidos para carbofurano.
\end{abstract}

A simple spectrophotometric method based on the coupling of a carbamate pesticide, carbofuran (2, 3-dihydro, 2, 2-dimethyl-7-benzofuranyl methyl carbamate) with diazotized $p$-aminoacetophenone (DPAAP) under alkaline condition is described. The orange dye formed by coupling of the pesticide with DPAAP was measured at $460 \mathrm{~nm}$. Beer's law is obeyed over the concentration range of 0.1 to $1.2 \mu \mathrm{g} \mathrm{mL}^{-1}$ of carbofuran in a final solution of $25 \mathrm{~mL}$. Molar absorptivity and Sandell's sensitivity were found to be $1.2 \times 10^{5} \mathrm{~L} \mathrm{~mol}^{-1} \mathrm{~cm}^{-1}$ and $0.0014 \mu \mathrm{g} \mathrm{cm}^{-2}$ respectively. The optimum reaction condition and other analytical conditions were evaluated. The effect of interfering ions on the determination of carbofuran is described. The method has been successfully applied to the determination of carbofuran in rice, wheat and various environmental and biological samples. The results obtained were compared with other spectrophotometric and chromatographic methods reported for carbofuran.

Keywords: spectrophotometric method, 2,3-dihydro-2, 2-dimethyl-7-benzofuranyl methylcarbamate, $p$-aminoacetophenone, environmental and biological samples

\section{Introduction}

Carbofuran (2,3-dihydro-2, 2-dimethyl-7-benzofuranyl methylcarbamate) is also known as Furadan, FMC, Curraterr and Yaltox. It is an effective contact and systemic broadspectrum carbamate insecticide and acarcicide. ${ }^{1-3}$ Carbofuran is registered for use in a variety of fruits, vegetables, grains and crops. It is widely used for protection of sugar beet seed, sorghum seeds and seedling from insect, pests in soil. ${ }^{4-6}$ Carbofuran is highly toxic for mammals. The acute oral $\mathrm{LD}_{50}$ value of carbofuran for rats is $5.0 \mathrm{mg} \mathrm{kg}^{-1} .^{7}$ Its toxic properties

*e-mail: drajaipillai@gmail.com include inhibitory effect on cholinesterase enzyme, violent convulsions and neuromuscular disturbance on inhalation. ${ }^{8}$ It is also reported to be mutagenic, genotoxic, teratogenic and affects the embryos. ${ }^{910}$ Due to its wide applicability and high toxicity, numerous chromatographic methods are reported for its determination such as High Performance Liquid Chromatography, ${ }^{11}$ solid phase micro extraction-High Performance Liquid Chromatography (combination of HPLC, GC/MS, LC-MS) ${ }_{12}^{12}$ Immunoaffinity Chromatography (Coupled Column Liquid Chromatography/Mass Spectrophotometry), ${ }^{13}$ Thin Layer Chromatography. ${ }^{14}$ Various spectrometric methods using different reagents like sulphanilic acid, ${ }^{15} p$-aminoacetanilide, ${ }^{16} p$-aminobenzoic 
acid ${ }^{17} p$-aminoantipyrine, ${ }^{18} 2,4$-dinitroaniline, ${ }^{19} p$-anisidine ${ }^{20}$ have also been reported for its determination. These methods suffer from some drawbacks like instability of color, interference from foreign ions, use of toxic reagents etc.

In the present work, a simple sensitive spectrophotometric method using a non-toxic reagent $p$-aminoacetophenone is reported for the determination of carbofuran in various environmental, biological and grain samples. The reaction is based on the coupling of carbofuran with diazotized $p$-aminoacetophenone in alkaline condition. The absorbance of the resulting azo dye was measured at $460 \mathrm{~nm}$. The proposed method has been applied for the determination of carbofuran in various environmental and biological samples.

\section{Experimental}

\section{Apparatus}

A Toshniwal TSVP model 25 visible spectrophotometer and a systronics digital pH meter model 335, was used for spectral and $\mathrm{pH}$ measurement respectively.

\section{Reagents}

All chemicals used were of analytical grade reagent or the best available quality and double distilled water was used throughout the experiment. $1 \mathrm{mg} \mathrm{mL}^{-1}$ Stock solution of carbofuran (Rallis India) was prepared in glacial acetic acid (1:10). Working standard was prepared by appropriate dilution of the stock solution. A 2 mol L ${ }^{-1}$ Sodium hydroxide solution (Loba chemie, Mumbai) was prepared. A 1\% (m/ v) p-aminoacetophenone (PAAP) (Loba chemie, Mumbai) was prepared in (1:5) hydrochloric acid. A $0.2 \%(\mathrm{~m} / \mathrm{v})$ Sodium nitrite (Loba chemie, Mumbai) aqueous solution was prepared daily. A 3\% (m/v) Sulphamic acid (Loba chemie, Mumbai) aqueous solution was used.

\section{Diazotized p-aminoacetophenone (DPAAP)}

Around 1\% PAAP was dissolved in (1:5) hydrochloric acid. To it $0.2 \%$ sodium nitrite solution was added and kept in an ice bath for $10 \mathrm{~min}$ for complete diazotization. Excess nitrite was removed by addition of $1 \mathrm{~mL}$ of $3 \%$ sulphamic acid.

\section{Preparation of calibration curve}

An aliquot containing 4-32 $\mu \mathrm{g}$ of carbofuran was taken in a $25 \mathrm{~mL}$ graduated test tube. To it $2 \mathrm{~mL}$ of DPAAP was added and kept for $5 \mathrm{~min}$, after which $3 \mathrm{~mL}$ of $\mathrm{NaOH}$ was added to it. An orange yellow dye was formed (Scheme 1). The solution was made up to the mark with distilled water. The dye was measured at $460 \mathrm{~nm}$ against double distilled water as reagent blank, which gave negligible absorbance at this wavelength (Figure 1).

Determination of carbofuran in polluted water, soil and foliages

Agricultural wastewater samples were taken from a field, where carbofuran had been sprayed as an insecticide and extracted with $2 \times 10 \mathrm{~mL}$ portion of chloroform. The chloroform extract was then evaporated to dryness and the residue was dissolved in $10 \mathrm{~mL}$ of (1:10) acetic acid. Aliquots were taken in $25 \mathrm{~mL}$ graduated test tube, coupled with DPAAP followed by addition of $3 \mathrm{~mL}$ of $\mathrm{NaOH}$ and analyzed.

Soil and foliage samples were taken from an agricultural field, where carbofuran had been used for insect control. These samples were weighed and extracted with $2 \times 10 \mathrm{~mL}$ chloroform and analyzed by the proposed method (Table 3 ).

Determination of carbofuran in rice and wheat

$10 \mathrm{~g}$ of rice and wheat samples were taken in a conical flask and fortified with known amount of carbofuran and extracted with $2 \times 10 \mathrm{~mL}$ of chloroform. The samples were subsequently analyzed by the reported method (Table 4$).{ }^{19}$

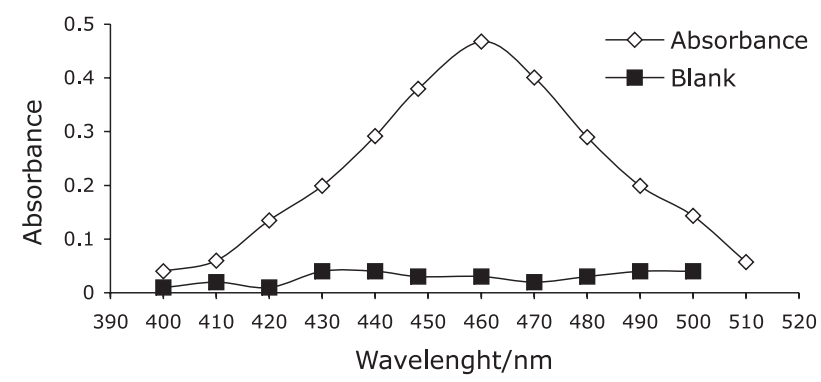

Figure 1. Absorption spectra of carbofuran at $18 \mu \mathrm{g}$ per $10 \mathrm{~mL}$ of concentration.

Table 1. Spectral and statistical parameters

\begin{tabular}{lc}
\hline Parameter & Result \\
\hline Stability of color & $\sim 12 \mathrm{~h}$ \\
$\lambda_{\max } / \mathrm{nm}$ & 460 \\
Limit of Beer's law $/\left(\mu \mathrm{g} \mathrm{mL}^{-1}\right)$ & 0.1 to 1.2 \\
Molar absorptivity $\left(\mathrm{L} \mathrm{mol}^{-1} \mathrm{~cm}^{-1}\right)$ & $1.2 \times 10^{5}$ \\
Sandell's sensitivity $/\left(\mu \mathrm{g} \mathrm{cm}^{-2}\right)$ & 0.0014 \\
Relative standard deviation & $2.4 \%$ \\
Standard deviation & \pm 0.009 \\
Regression equation $(\mathrm{y}=\mathrm{ma}+\mathrm{c})_{\text {Slope }^{\mathrm{a}}}$ & \\
Intercept $^{\mathrm{c}}$ & 0.56 \\
Correlation coefficient $^{-14}$ & 0.015 \\
\hline
\end{tabular}


Table 2. Effect of foreign species and pesticides

\begin{tabular}{lc}
\hline $\begin{array}{l}\text { Effect of foreign species } \\
\text { and pesticides }\end{array}$ & $\begin{array}{c}\text { Tolerance limit*/ } \\
\left(\mu \mathrm{g} \mathrm{mL}^{-1}\right)\end{array}$ \\
\hline Ethanol & 10,000 \\
Methanol & 8,750 \\
Formaldehyde & 1,000 \\
Carbosulfan & 250 \\
Phorate & 800 \\
Ethyl parathion & 500 \\
Nitrophenol & 150 \\
Cresol & 150 \\
\hline
\end{tabular}

*The amount causing an error of $\pm 2 \%$ in absorbance value.

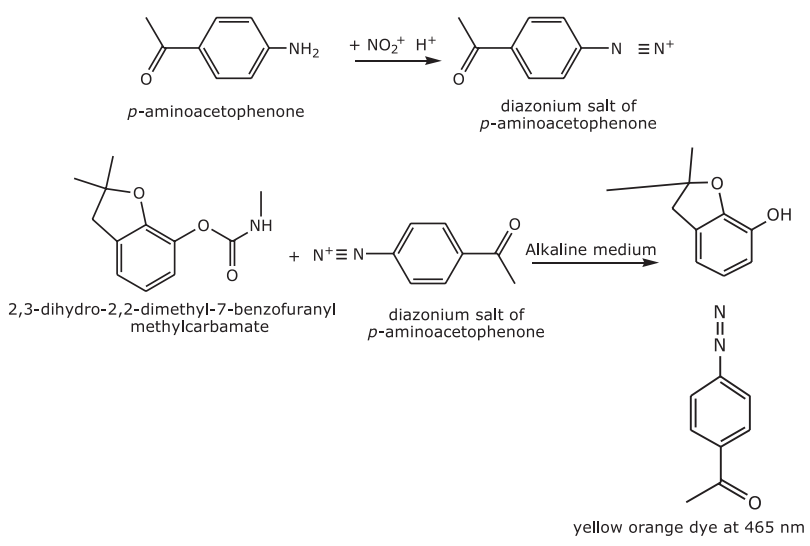

Scheme 1. Colour reaction.

\section{Determination of carbofuran in biological samples}

The presence of carbofuran has been reported in blood and urine samples. ${ }^{21}$ Spiked samples were prepared by adding known amount of carbofuran in blood and urine samples. The samples were deproteinised with trichloroacetic acid ${ }^{22}$ and extracted with $2 \times 5 \mathrm{~mL}$ of chloroform. The chloroform extract was than evaporated to dryness and the residue was dissolved in $10 \mathrm{~mL}$ of (1:10) acetic acid. Aliquots were taken in $25 \mathrm{~mL}$ graduated test tube and analyzed as described above (Table 5).

\section{Results and Discussion}

\section{Spectral characteristic}

The color system shows maximum absorbance at $460 \mathrm{~nm}$. All spectral measurements were carried out against demineralized water.

\section{Adherence to Beer's law, molar absorptivity, Sandell's sensitivity}

The response was linear between concentration range 4 to $32 \mu \mathrm{g}$ of carbofuran per $25 \mathrm{~mL}$ ( 0.1 to $1.2 \mu \mathrm{g} \mathrm{mL}^{-1}$ ).
The molar absorptivity and Sandell's sensitivity were found to be $1.2 \times 10^{5} \mathrm{~L} \mathrm{~mol}^{-1} \mathrm{~cm}^{-1}$ and $0.0014 \mu \mathrm{g} \mathrm{cm}^{-2}$ respectively (Table 1).

\section{Effect of acidity}

The effect of acidity for the diazotization was studied ranging from 0.1 to $5 \mathrm{~mol} \mathrm{~L}^{-1}$. It was found that $\sim 2.4 \mathrm{~mol}$ $\mathrm{L}^{-1} \mathrm{HCl}$ was necessary for complete diazotization.

\section{Effect of nitrite concentration}

It was found that $1.3 \mathrm{~mL}$ of $0.2 \%$ sodium nitrite was sufficient for complete diazotization. It gives constant and maximum absorbance. Excess nitrite was removed by sulphamic acid.

\section{Effect of alkalinity}

It was found that $3 \mathrm{~mL}$ of $2 \mathrm{~mol} \mathrm{~L}^{-1} \mathrm{NaOH}$ was sufficient for complete color development. More than 3 $\mathrm{mL}$ of $\mathrm{NaOH}$ decreased the absorbance.

\section{Effect of $p H$}

Maximum absorbance and stability of the dye was observed between $\mathrm{pH} 12-13$, below or above which the absorbance value decreased.

\section{Effect of diazotized DPAAP}

It was found that $2 \mathrm{~mL}$ of DPAAP solution was sufficient for constant and maximum absorbance.

\section{Effect of time and temperature}

Diazotization of PAAP was completed in $15 \mathrm{~min}$ at temperature below $5{ }^{\circ} \mathrm{C}$. The coupling reaction was optimized at room temperature. At higher temperature absorbance as well as stability of dye decreased. The color of the dye formed by the reaction was found to be stable for $\sim 12 \mathrm{~h}$.

\section{Effect of foreign species}

The effect of common foreign species and pesticides, which are likely to interfere in the proposed reaction for the determination of carbofuran, was studied. Known amount of foreign species and pesticides were added to a standard solution containing $18 \mu \mathrm{g}$ of carbofuran in $25 \mathrm{~mL}$ of final solution, prior to 
Table 3. Determination of carbofuran in spiked water, soil and foliage samples

\begin{tabular}{lcccc}
\hline Samples & $\begin{array}{c}\text { Amount of carbofuran } \\
\text { added } / \mu \mathrm{g}^{\mathrm{a}}\end{array}$ & $\begin{array}{c}\text { Amount of carbofuran } \\
\text { found } / \mu \mathrm{g}\end{array}$ & \multicolumn{2}{c}{ Recovery/(\%) } \\
(A)
\end{tabular}

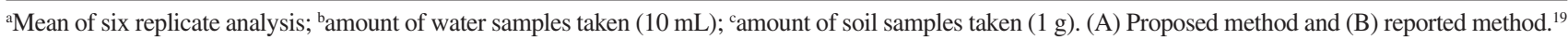

Table 4. Determination of carbofuran in spiked wheat and rice grain

\begin{tabular}{|c|c|c|c|c|c|}
\hline \multirow[t]{2}{*}{ Samples } & \multirow[t]{2}{*}{ Amount of carbofuran added $/ \mu \mathrm{g}$} & \multicolumn{2}{|c|}{ Amount of carbofuran found $/ \mu \mathrm{g}$} & \multicolumn{2}{|c|}{ Recovery/(\%) } \\
\hline & & (A) & (B) & (A) & (B) \\
\hline \multirow[t]{2}{*}{$\operatorname{Rice}^{\mathrm{b}}(1 \mathrm{~g})$} & 10.00 & 9.76 & 9.60 & 97.60 & 96.00 \\
\hline & 20.00 & 19.25 & 19.00 & 97.20 & 95.00 \\
\hline \multirow[t]{2}{*}{ Wheat $^{\mathrm{c}}(1 \mathrm{~g})$} & 10.00 & 9.58 & 9.50 & 95.80 & 95.00 \\
\hline & 20.00 & 18.85 & 18.50 & 94.21 & 92.50 \\
\hline
\end{tabular}

${ }^{\mathrm{a}}$ Mean of six replicate analysis; ${ }^{\mathrm{b}}$ amount of rice samples taken $(1 \mathrm{~g})$; ${ }^{\mathrm{c} a m o u n t}$ of wheat samples taken $(1 \mathrm{~g}) .(\mathrm{A})$ Proposed method and (B) reported method. ${ }^{19}$

Table 5. Determination of carbofuran in biological samples

\begin{tabular}{|c|c|c|c|c|c|}
\hline \multirow[t]{2}{*}{ Samples } & \multirow[t]{2}{*}{ Amount of carbofuran added $/ \mu \mathrm{g}$} & \multicolumn{2}{|c|}{ Amount of carbofuran found $/ \mu \mathrm{g}$} & \multicolumn{2}{|c|}{ Recovery/(\%) } \\
\hline & & (A) & (B) & (A) & (B) \\
\hline \multirow[t]{2}{*}{$\operatorname{Blood}^{\mathrm{b}}(1 \mathrm{~mL})$} & 5.00 & 4.92 & 4.98 & 98.20 & 97.80 \\
\hline & 10.00 & 9.76 & 9.72 & 97.60 & 97.20 \\
\hline \multirow[t]{2}{*}{ Urine $^{\mathrm{b}}(1 \mathrm{~mL})$} & 5.00 & 4.93 & 4.90 & 98.60 & 98.00 \\
\hline & 10.00 & 9.88 & 9.76 & 98.80 & 97.60 \\
\hline
\end{tabular}

${ }^{\mathrm{a}}$ Mean of six replicate analysis; ${ }^{\mathrm{b} a m o u n t}$ of samples taken $(\mathrm{mL})$. (A) Proposed method and (B) reported method. ${ }^{19}$

Table 6. Comparison with other reported spectrophotometric and chromatographic methods

\begin{tabular}{|c|c|c|c|}
\hline Reagent & $\lambda_{\max } /(\mathrm{nm})$ & Limit of Beer's Law/ $\left(\mu \mathrm{g} \mathrm{mL}^{-1}\right)$ & Remarks \\
\hline \multicolumn{4}{|l|}{ Spectrophotometric methods } \\
\hline$p$-aminoantipyrine ${ }^{18}$ & 475 & $0.5-20$ & Less stable \\
\hline$p$-aminobenzoic acid ${ }^{17}$ & 490 & $0.4-12$ & Poor sensitivity \\
\hline$p$-anisidine $\mathrm{e}^{20}$ & 660 & $0.1-1.2$ & Reagent highly toxic \\
\hline 2,4-dinitroaniline ${ }^{19}$ & 526 & $0-10$ & Less sensitive \\
\hline$p$-aminoacetanilide ${ }^{16}$ & 465 & $0.5-16$ & Less sensitive \\
\hline $\begin{array}{l}p \text {-aminoacetophenone } \\
\text { (present work) }\end{array}$ & 460 & $0.1-1.2$ & $\begin{array}{l}\text { Non-toxic, dye remains } \\
\text { stable for } \sim 12 \mathrm{~h} .\end{array}$ \\
\hline \multicolumn{4}{|l|}{ Chromatographic methods } \\
\hline HPLC $^{11}$ & - & $0.05-0.1$ & Methods are very sensitive \\
\hline SPME-HPLC ${ }^{12}$ & 205 & $1 \times 10^{-9}$ & but instruments are \\
\hline Immunoaffinity ${ }^{13}$ chromatography & - & $4 \times 10^{-11}$ & very expensive. \\
\hline
\end{tabular}

coupling with DPAAP and then analyzed by the proposed method (Table 2).

\section{Reproducibility}

Reproducibility of the method was checked by the replicate analysis of solution containing $18 \mu \mathrm{g}$ per 25 $\mathrm{mL}$ of carbofuran over a period of 7 days. The standard deviation and relative standard deviation were found to be \pm 0.009 and $2.4 \%$ respectively (Table 1 ).

\section{Conclusions}

The proposed method provides a simple method for determination of carbofuran and was found to be free from the interference of a large number of foreign species and 
toxic reagents. The method was compared with other spectrophotometric and chromatographic methods (Table 6). The method has been found to be superior to other spectrophotometric methods, while chromatographic methods although superior involves tedious steps. The method was applicable in soil, water, grains and biological samples.

\section{Acknowledgment}

The Authors are grateful to Govt. V.Y.T. PG Autonomous College, Durg (C.G.) for providing laboratory facilities.

\section{References}

1. Chopra, S. L.; Kanwar, J. S.; Analytical Agricultural Chemistry, $4^{\text {th }}$ ed., Kalyani Publishers: Ludhiana, 1991, p. 421.

2. Stevens, R. W.; Pesticides in the Environment, Part 1, Marcel Dekker Interscience: New York, 1977, vol.1, p. 112.

3. Hill, E. F.; Camardese, M. B.; Ecotoxicol. Environ. Saf. 1984, 8,55 .

4. Hamm, J. G.; The Handbook of Pest Control; Fredrick Fell Publishers Inc.: New York, 1982, p. 55.

5. Heijbroek, W.; Hujibregts, A.W.M.; Crop. Prot. 1995, 14, 365.

6. Tobin, J. S.; Journal of Occupational Medicine 1970, 12, 16.

7. Sutt, D. L.; Crop. Prot. 1987, 6, 371.
8. Toxic and Hazardous Industrial Chemical, Safety Manual for Handling and Disposal with Toxicity and Hazard Data; International Technical Information Institute: Japan, 1994, p. 357.

9. Cohen, S. M.; Cano, M.; Johnson; L. S.; John, M. K.; Asmoto, M.; Gerland, E. M.; Tyssen, J. H.; Sangha, G. K.; Van Goethem, D. L.; Carcinogenesis 1994, 15, 2593.

10. Sharma, B.; Gopal, K.; Toxicol. Environ. Chem. 1995, 47, 89.

11. Krause, R. T.; J. Chromatogr. 1988, 17, 333.

12. Aulakh, J. S.; Malik, A. K.; Kaur, V.; Kopplin, P. S.; Anal. Chem. 2005, 35, 71 .

13. Sucsse, H.; Mucller, H. J.; Chromatogr. A 1996, 730, 337.

14. Quintero, M. D. C.; Silva, M.; Perez, D.; Analyst 1989, 114, 497.

15. Agrawal, O.; Gupta, V. K.; Microchem. J. 1999, 62, 147.

16. Harikrishna, V.; Prasad, B.; Naidu, N. V. S.; J. Indian Chem. Soc. 2005, 82, 185.

17. Rajeshwari, C. V.; Naidu, P. R.; J. Food Sci. Technol. 1986, 23 , 101.

18. Appaiah, K. M.; Ramkrishna, K. R.; Rao, S.; Nagaraja, K. V.; Kapoor, O. P.; J. Food Sci. Technol. 1982, 19, 211.

19. Harikrishna, V.; Prasad, B.; Naidu, N. V. S.; Journal of the Indian Council of Chemists 2003, 20, 42.

20. Kesari, R.; Das, J. V.; Gupta, V. K.; J. Ind. Chem. Soc. 1999, $75,182$.

21. Os' Kina, V. N.; Gig. Sanit. 1982, 7, 45 (Russ); Anal. Abst. 1983, 45, 112 (Eng.).

22. Aldridge, W. N.; Analyst 1994, 334.

Received: October 29, 2005

Web Release Date: March 9, 2007 